tyczne; 7. Zagadnienia dydaktyczno-metodyczne katechezy; 8. Wychowanie chrześcijańskie; 9. Katechetyka a wybrane dyscypliny naukowe. Ten ogólny podział z kolei zaskakuje szczegółowym podziałem wewnętrznym każdego z działów. Wydaje się więc, że w sposób optymalny zapewniono łatwy sposób dotarcia do rozmaitych zagadnień przedmiotu.

Nas interesuje, oczywiście, zbiór opracowań dotyczących katechezy okresu patrystycznego. Informacje na ten temat zamieszczono w dziale 1: Fundamentalne problemy katechezy. Historia katechezy w poddziale 1. 8 (Katecheza w pierwszych wiekach chrześcijaństwa, s. 114-115). Znajdujemy tu wykaz 26 publikacji omawiających wkład Ojców Kościoła w rozwój myśli katechetycznej (św. Ambroży, św. Augustyn, św. Hieronim, św. Jan Chryzostom, Klemens Aleksandryjski, Rufin z Akwilei), nauczania Kościoła pierwotnego oraz znaczenia katechezy patrystycznej dla współczesnych. Odnotowano także tłumaczenia pism i tekstów katechetycznych Ojców Kościoła. W poddziale 1.9 (Historia katechezy, s. 115-116) wskazano na opracowanie dotyczące historii katechezy w ogóle oraz artykuł poświęcony formowaniu osobowości integralnej za pomocą Reguty św. Benedykta. Nawet gdy dodamy pominięte przez wykaz 10 artykułów o różnych aspektach katechezy patrystycznej z „Vox Patrum", to i tak stan polskiej refleksji katechetycznej nad dorobkiem Ojców Kościoła w tej dziedzinie teologii pastoralnej przedstawia się nader skromnie. O potrzebie sięgania do Tradycji przekonuje nas na przykład praktyka Kościoła współczesnego, który w sytuacji coraz bardziej powszechnej praktyki chrztu dorosłych oraz podkreślania znaczenia ewangelizacji i personalizacji wiary sięga do wypróbowanej praktyki katechumenatu, wskazując na potrzebę rozwoju formacji deutero- lub neokatechumenalnych w parafii. Dodajmy, że Autorzy Bibliografii pominęli w wykazie opracowania podejmujące omówienie tego tematu w życiu Kościoła pierwszych wieków: B. Mokrzyckiego (Droga chrześcijańskiego wtajemniczenia, Warszawa 1983, s. 38-197), M. Dujariera (Krótka historia katechumenatu, Poznań 1990) oraz S. Movilli (Od katechumenatu do wspólnoty, Warszawa 1990).

Marek Marczewski - Lublin

\title{
G.W. BOWERSOCK, Martyrdom and Rome. The Wiles Lectures given at the Queen's University of Belfast, Cambridge 1995, ss. 106.
}

Warto zapoznać się z jedną z najnowszych prac autorstwa G.W. Bowersocka, której tytuł: Martyrdom and Rome, najpełniej oddaje jej treściową zawartość. Stanowi ona ciekawy, a zarazem oparty na mocnej podstawie źródłowej, przykład monografii, wnoszącej nowy, oryginalny sposób podejścia do, zdawałoby się dogłębnie już przeanalizowanego zagadnienia. W swoich badaniach 
Autor koncentruje się na możliwie wszechstronnej analizie koncepcji męczeńskiej śmierci za wiarę. Jest to bowiem zjawisko stanowiące istotny i stale aktualny aspekt życia społeczeństw, choć współcześnie trudno byłoby odnosić je do jednej, określonej grupy wyznaniowej. Porusza więc w pierwszej kolejności, problem genezy tego fenomenu, próbując jednocześnie określić ramy czasowe, w których zjawisko to uległo ostatecznej krystalizacji. Następnie analizuje zachowane Akta Męczenników (Acta Martyrum) pod kątem wyodrębnienia ich zasadniczego, podstawowego komponentu, jaki stanowią trzy typy autentycznych, współczesnych opisywanym wydarzeniom dokumentów. Zwraca następnie uwagę na mocne osadzenie męczeństwa w strukturach Imperium Romanum, w mentalności i religijności rzymskiej, w obyczajowości mieszkańców basenu Morza Śródziemnego; podkreśla specyficznie miejski kontekst zjawiska. Znaczną część swojej pracy Bowersock poświęca problematyce dobrowolnego wyboru śmierci za wiarę. Szczegółowo analizuje przy tym stanowisko władz kościelnych wobec takiej postawy wiernych. Akcentuje znaczenie samobójstwa w starożytnym Rzymie i w koncepcjach filozoficznych tego okresu, dostrzegając zasadniczą w tej mierze odmienność zapatrywań systemów: stoickiego i platońskiego. Znacznie większy wpływ drugiego z wymienionych na myśl teologiczną Kościoła pierwszych wieków pociąga za sobą istotne konsekwencje. W efekcie stajemy się świadkami definitywnego potępienia autodenuncjacji. Jak więc widzimy, Autor pomija całkowicie polityczno - prawny aspekt śmierci męczeńskiej. Nie interesują go przyczyny prześladowań, ich przebieg czy wreszcie stosunek pogańskiej społeczności do religio christiana. Za istotne, ze swego punktu widzenia uznaje jednak sposób jej zachowania się wobec męczenników i ich pragnienia dania świadectwa Chrystusowi. Koncentruje się więc na samym zjawisku: jego genezie, specyfice, związkach z obyczajowością ówczesnych mieszkańców Imperium oraz podkreśla ewolucyjny charakter koncepcji.

W rozdziale pierwszym (The making of martyrdom, ss. 1-21) Autor podejmuje problematykę kształtowania się koncepcji męczeńskiej śmierci. Wstępem do zasadniczego toku rozważań w tym rozdziale, jest opis wydarzenia, zaczerpniętego z otwartego listu Do Skapuli Tertuliana. C. Arrius Antoninus staje w obliczu grupy chrześcijan przybyłych dobrowolnie i podobnie też przyznających się do swojej wiary. Oczekują śmierci, co więcej, oni wychodzą jej naprzeciw. Postawa taka budzi powszechne zdziwienie wśród pogan (choć nie można wykluczyć, że i wśród współwyznawców), zmusza do refleksji nawet władców. Jak wytłumaczyć tak irracjonalne, zdawałoby się, poszukiwanie śmierci? W jaki sposób odniesie się do niego intelektualna elita Kościoła? Już w tym miejscu autor wzmiankuje o dokonanym stopniowo rozgraniczeniu między śmiercią dobrowolną, a męczeństwem - wynikiem prześladowania. Takie duchowe autorytety jak Klemens Aleksandryjski, Cyprian czy Laktancjusz, zmierzają do zahamowania niepokojącego entuzjazmu wiernych oraz pozostawienia peł- 
nej glorii wyłącznie tym, którzy cierpieli i zginęli w efekcie prześladowań, lecz nie $z$ własnej winy.

Autor proponuje z kolei przyjrzenie się genezie zjawiska męczeńskiej śmierci. Fenomen ów nie towarzyszy antykowi od jego zarania. Gdzie i kiedy więc szukać jego początków? - pozostaje to nadal kwestią sporną. Bowersock nie żywi złudzeń, że jego analiza rozproszy wszelkie w tej materii wątpliwości, ma jednak nadzieję na pewne naświetlenie drogi rozwojowej omawianego zjawiska. Autor stwierdza, iż narodzin tej koncepcji należy szukać w środowisku pierwszych wyznawców Chrystusa. Stanowi ona bowiem naturalną konsekwencję chrześcijańskiej postawy wobec świata, pragnienia bycia świadkiem Chrystusa i apostołem Dobrej Nowiny. Chrześcijańska religijność była więc impulsem dla narodzin fenomenu męczeństwa. Dalszy zaś jego rozwój przebiega w stałym związku z otaczającym wyznawców Chrystusa pogańskim światem. W dalszym ciągu swojego wywodu autor dokonuje uściślenia granic czasowych, między którymi dochodzi do uformowania interesującego nas zjawiska. Zauważa jednak, że samo pragnienie śmierci za wiarę wyprzedza narodziny opisującej je terminologii, bazującej na określeniu zaczerpniętym ze słownictwa prawniczego, i oznaczającym świadka. Autor przyjmuje, że nastąpiło to w okresie pomiędzy 50 a 150 rokiem po Chrystusie. Najwcześniejsze użycie słowa martyrs w interesującym nas, odmiennym od pierwotnego, znaczeniu, miało miejsce dopiero ok. 150 roku, a więc stanowi niejako podsumowanie całego procesu.

Kolejny, drugi rozdział swojej pracy (The written record, ss. 23-39), G.W. Bowersock poświęca zachowanym do naszych czasów Aktom Męczenników. Ich pierwotny tekst ulegał, często daleko posuniętym uzupełnieniom i zmianom. Akta stanowiły bowiem fragment twórczości literackiej wczesnego chrześcijaństwa i cieszyły się niesłabnącą popularnością, a nawet więcej; Autor podkreśla istnienie bezpośredniego związku między dynamicznym rozwojem tego gatunku piśmiennictwa, a schyłkiem uprawianej dotąd w Imperium tzw. fikcji historycznej. Teksty chrześcijańskie, odpowiadające potrzebom czytelników w ten sam sposób, w jaki wcześniej czyniła to właśnie fikcja, są jednocześnie cennym zbiorem autentycznego materiału historycznego. Ponieważ zarówno martyrologia, jak i hagiografia rozwinęły się w czasach panowania następców Konstantyna, zawartość historyczna tych narracji ulegała pomniejszeniu, lecz nie możemy twierdzić, że uległa całkowitej eliminacji. Dlatego też, najwcześniejsze Akta stanowią istotny materiał źródłowy. Bowersock wskazuje na możliwość wyodrębnienia aż trzech komponentów składających się na najstarszą, podstawową ich redakcję. Są to, po pierwsze: fragmenty „dzienników” prowadzonych przez samych bohaterów; po drugie: relacje naocznych świadków opisywanych wydarzeń (często ów świadek jest zarazem pierwszym redaktorem $A k t$ ), i po trzecie: raporty sądowe z przebiegu przesłuchania męczennika. W podsumowaniu Autor zauważa, iż na podstawie analizy $A k t$ można 
wysnuć wniosek, że męczeństwo stanowi zjawisko silnie związane ze światem grecko-rzymskim, jego tradycjami, językiem i gustami kulturalnymi. W opinii Bowersocka, chrześcijaństwo niejako „zawdzięcza” swoich bohaterów zwyczajom i strukturze rzymskiego państwa. Nie można się temu dziwić. Kim bowiem byli chrześcijanie, jeśli nie mieszkańcami Imperium? Nie żyli przecież w izolacji od świata, w którego ramach narodziła się ich wiara; jego instytucje i obyczajowość były jedynymi, jakie znali i, przynajmniej częściowo, akceptowali.

Już na wstępie kolejnego, trzeciego rozdziału (The civic role of martyrs, ss. 41-57), Autor podkreśla miejski kontekst zjawiska męczeńskiej śmierci. Zauważa przy tym, że chodzi przede wszystkim o największe ośrodki miejskie rzymskiego świata, a zwłaszcza wschodniej jego części. Bowersock stawia sobie pytanie o przyczynę takiej właśnie lokalizacji przykładów męczeństwa. Wniosek nasuwa się jednoznacznie: tylko w ramach dużych miast przykład wyznawcy mógł odegrać swoją rolę, wywrzeć wrażenie na lokalnej społeczności, zmusić do refleksji. Męczennicy, jak słusznie akcentuje Autor, to nauczyciele i przewodnicy społeczności chrześcijańskiej, na wzór sławnych sofistów tego okresu. Cechą charakterystyczną antycznych szkół filozoficznych i retorycznych było postrzeganie społeczności: mistrz - uczniowie, jako rodzaju duchowej rodziny. Przejęcie tego języka dla oddania relacji wewnętrznych w gminach chrześcijańskich stanowi kolejny dowód, potwierdzający istnienie silnego związku nowej wiary ze światem, w którym się rozwijała. Słowa, z jakimi „nauczyciel” zwraca się do otaczających go tłumów, mogą być porównywane z pracami ówczesnych wybitnych myślicieli. W dalszej części pracy, Autor stara się wykazać istnienie ścisłego związku między męczeństwem a różnego typu uroczystościami, towarzyszącymi życiu lokalnych społeczności. Nie bez powodu sposób, w jaki umierają wyznawcy Chrystusa wykazuje znaczne podobieństwo do postawy wielkich atletów i gladiatorów. Śmierć w amfiteatrze to ważny aspekt męczeństwa wczesnego Kościoła. W wizji kartagińskiej męczennicy Perpetui, Chrystus występuje jako agonothetes, czyniący igrzyska, które urastają w ten sposób do rangi zamierzonego, boskiego zrządzenia. Urzędnicy rzymscy i sami chrześcijanie jedynie ,grają" w nim wyznaczoną rolę. Oba te komponenty: zarówno sofistyczny jak i agonistyczny, stanowią kolejne świadectwo silnej integracji męczeństwa ze społecznością Imperium. Bez tychże czynników zjawisko to prawdopodobnie nie mogłoby w ogóle zaistnieć.

Zamykający pracę Bowersocka rozdział czwarty (Martyrdom and suicide, ss. 59-74), poszerza, zasygnalizowane w początkowej części utworu, rozważania na temat relacji między męczeństwem a samobójstwem. Autor analizuje dostępne nam relacje źródłowe, starając się określić postawę chrześcijan w czasie procesu i egzekucji. Zwraca uwagę na ich spokój, pełne radości oczekiwanie, a nawet entuzjazm. Wyznawcy Chrystusa pragną dawać świadectwo swej wierze, nawet jeśli oznacza to autodenuncjację. I ten właśnie aspekt męczeństwa powoduje ożywioną dyskusję wśród chrześcijan. Ostatecznie teologowie Koś- 
cioła uznają, że samobójstwo (w tych bowiem kategoriach należy rozważać dobrowolną śmierć), nie może jednocześnie być męczeństwem, ponieważ oba zjawiska znajdują się w zasadniczej sprzeczności wobec siebie. Autor zwraca w tym miejscu uwagę na istotny fakt. Analizując stanowisko Tertuliana wobec dobrowolnego męczeństwa, podkreśla, że samobójstwo w świecie rzymskim stanowiło honorowy sposób obrony własnych ideałów. Było też zjawiskiem akceptowanym przez stoików, o ile decyzja ta została podjęta świadomie i służyła wyższym celom. Nie odrzucali samobójstwa także cynicy. W poglądach i postawie Tertuliana jest więc coś wyraźnie rzymskiego. Bowersock wskazuje nawet na wyraźne podobieństwo sformułowań i myśli tego twórcy z dziełami Cycerona oraz listami Seneki. W zasadniczo odmienny sposób podchodzi do tego problemu filozofia platońska: tu widoczny jest sprzeciw wobec jakiejkolwiek formy przemocy dokonanej na własnej osobie, a nie ulega wątpliwości, że ten właśnie system filozoficzny miał znaczny wpływ na wczesnochrześcijańskich teologów i intelektualistów. Stanowi to zarazem świadectwo powrotu do tradycji świata greckiego, i przesuwania akcentu rzymskiej państwowości, już w tym okresie, na jego wschodnią część. Bez gloryfikacji samobójstwa w tradycji rzymskiej, rozwój koncepcji męczeństwa w II i III wieku, byłby nie do pomyślenia. Tak grecka jak i żydowska mentalność były jej bowiem przeciwne.

Końcowe strony swojej pracy G.W. Bowersock poświęca uzupełnieniu niektórych, wybranych zagadnień, sygnalizowanych już w zasadniczym toku rozważań. Pozostają one w luźnym związku z głównym nurtem przemyśleń autora, stąd ich zamieszczenie w czterech kolejnych appendiksach służy lepszej organizacji tekstu i, nie wprowadzając zbędnych dygresji do podstawowej części pracy, ułatwia jej odbiór. Próbuje więc wskazać na świadectwa stanowiące pierwsze oznaki narodzin idei męczeństwa zawarte w tekstach Nowego Testamentu, dokonuje analizy porównawczej listów Ignacego Antiocheńskiego i Ksiąg Machabejskich pod kątem pewnych analogii językowych i niektórych sformułowań (Protomartyr, ss. 75-76 oraz Ignatius and IV Maccabees, ss. 77-8I). Proponuje wreszcie czytelnikowi powrót do koncepcji związków męczeństwa z życiem miejskim i jego obyczajowością, koncentrując się nad zagadnieniem Wielkiej Soboty; zwraca uwagę na specyfikę (również pod względem administracyjnym) azjatyckich prowincji Imperium (Great Sabbath, ss. 82-84; Asia, Aphrodisias, and the Lyon Martyrium, ss. 85-98). Utwór zamyka zestawienie bibliografii oraz indeksy.

Dzięki monografii Bowersocka możemy prześledzić kierunek zmian, jakim ulegała idea męczeńskiej śmierci. Pozwala nam to uzmysłowić sobie rolę przemian mentalności i wpływ tychże na proces kształtowania się ideologii oraz na stopniową ewolucję, uformowanych znacznie wcześniej i w odmiennych warunkach, koncepcji i pojęć. Autor stale odwołuje się do tych samych fragmentów relacji źródłowych, dobranych w ten sposób, by jednocześnie naświetlać 
różnorodne aspekty zjawiska. Odbiór dzieła, jak i zrozumienie prezentowanych w nim zagadnień, staje się przez to łatwiejsze. Struktura pracy zwraca uwagę swoją przejrzystością i logiką wywodu. Podstawowe jej założenia stanowią przy tym przedmiot stałych odwołań - co niewątpliwie służy ich utrwaleniu w świadomości czytelnika. Autor przedstawia przy tym spójną, przemyślaną koncepcję, bazującą na trwałych podstawach. Wszystko to razem sprawia, że monografia G.W. Bowersocka stanowi pozycję godną polecenia nie tylko naukowcom, o głębokiej znajomości problemu, lecz również szerszemu gronu czytelników, zważywszy na aktualność tematu męczeństwa i towarzyszące mu zaangażowanie emocjonalne. Warto więc, na kanwie tej pracy, zastanowić się głębiej nad genezą zjawisk i czynnikami, które pozwoliły na jego dalsze kształtowanie się, jak i nad niezwykłą trwałością tego fenomenu. W podsumowaniu pragnę jednak zaznaczyć, iż zaprezentowane powyżej poglądy należą do wysoce kontrowersyjnych. Stwarza to oczywiście możliwość szczególnie ożywionej polemiki, zwłaszcza, że problem męczeńskiej śmierci stanowi jedno z fundamentalnych zagadnień dziejów wczesnego chrześcijaństwa.

\title{
Paulina Rabiej - Kielce
}

\begin{abstract}
Bazil Vel'ký sv., Povzbudenie mladým, [aby využivali hodnoty svetskej literatury]. Listy, I (r. 357-374), preložil a vysvetlivky spracoval Daniel Škoviera ${ }^{1}$, uodnú študiu napísal Cyril Šesták $\mathbf{S J}^{2}$, register zostavil Andrej Škoviera ${ }^{3}$, Prešov 1999, Naboženské vydavatel'stvo PETRA, Bibliotheca Antiqua Christiana ${ }^{4}$, Edičný rad Patrimonium zv[äzok] 1, ss. 297, nlb. 7, mapa 1.
\end{abstract}

Niemałego wysiłku tłumacza i odwagi wydawnictwa wymagało przygotowanie niecodziennej publikacji - przekładu z języka greckiego na język słowac-

${ }^{1}$ Daniel Škoviera, urodzony 30 XI 1946 r. w Mikulaszowej, pow. Bardiejów, studia specjalistyczne w zakresie filologii klasycznej i romanistyki ukończył na Wydziale Filozoficznym Uniwersytetu J.A. Komenského w Bratysławie w roku 1970. Tam też na podstawie pracy poświęconej Persjuszowi i jego satyrom, w 1973 r. uzyskał doktorat, a w roku 1993, po przyjęciu pracy o slowackim humaniście Leonardzie Stoeckelu, przyznano mu tytuł docenta. Oprócz zajęć w macierzystym uniwersytecie J.A. Komenského docent D. Škoviera pracuje również na Wydziale Humanistycznym Uniwersytetu Trnawskiego, który stał się wydawcą recenzowanego tomu Listów św. Bazylego Wielkiego.

${ }^{2}$ Cyril Šestak SJ, słowacki jezuita, studiuje obecnie patrystykę na Wydziale Teologicznym w München.

${ }^{3}$ Anrej Škoviera, urodzony 15 III 1975 r. w Bratysławie, jest absolwentem Greckokatolickiego Wydziału Teologicznego w Preszowie.

${ }^{4}$ Pod lacińskim tytułem serii wydawniczej umieszczono również jego wersję w języku słowackim jako: Krest'anská Antická Bibliotéka. 